\title{
A TREE VOLUME TABLE FOR RED PINE BY CROWN WIDTH AND HEIGHT ${ }^{1}$
}

\author{
By G. M. BONNOR ${ }^{2}$
}

George Michael Bonnor was born in 1938; he came to Canada in 1957 and attended the University of Toronto. Upon graduation in 1961 with a B.SC.F. degree, he joined the Department of Forestry in his present position.

\section{ABSTRACT}

A multiple regression analysis of parameters which can be measured or interpreted on aerial photographs showed that crown width and tree height exhibit a good correlation with diameter at breast height. A tree volume table based on the above relationship was constructed and tested with good results.

\section{RESUME}

Une analyse par équations régressives multiples des paramètres qu'on peut mesurer ou interpréter sur photographies aériennes, a révélé que la hauteur d'un arbre et le diamètre de son houppier sont en corrélation assez étroite avec le diamètre du tronc à hauteur de poitrine. Une table de calcul du volume sur pied, fondée sur la corrélation ci-dessus, a été établie et éprouvée; les résultats sont assez probants.

\section{INTRODUCTION}

Aerial photographs have been used for several decades as a tool in forest inventory work. In the field of volume determination, however, measurements on aerial photographs have been limited mostly to stand parameters; for example, aerial stand volume tables have been constructed on basis of the correlation of volume per acre with average stand height and canopy density.

In recent years, aerial photography has improved considerably, and it has become possible to take large-scale photographs of good quality. Many foresters believe that sufficiently accurate measurements can be made on these photographs of individual tree dimensions for the estimation of tree volume. Used in conjunction with a limited amount of ground cruising, this "photo-cruising" method could reduce the cost of obtaining forest inventories without a sacrifice of accuracy. Large-scale $(1: 330)$ photographs have been tested by the Department of Forestry, Canada, Forest Inventories Section; the tests indicate that a species separation of the conifers is quite feasible, and that several parameters of individual trees can be accurately measured (Kippen and Sayn-Wittgenstein, 1964). Similar tests by Lyons (1961) confirm these conclusions.

The purpose of the present study was to find those parameters measurable or interpretable on large-scale aerial photographs which give the best prediction of individual tree volumes.

\footnotetext{
1 Department of Forestry, Canada, Forest Research Branch Contribution No. 619.

2 Research Officer, Forest Inventories Section, Forest Research Branch, Department of Forestry, Ottawa.
} 


\section{(a) Sampling Design}

\section{METhoD}

To construct a tree volume table for use with aerial photographs, one of the following two methods can be used:

(i) obtain ground measurements of individual tree volumes (V) and of those variables which can be measured on the photographs; apply the data to a multiple regression analysis, and select the variables giving the best correlation with (V); construct the table on basis of this best regression equation;

(ii) obtain ground measurements of diameter at breast height (D) and of those variables which can be measured on the photographs; apply the data to a multiple regression analysis, and select the variables giving the best correlation with (D). Using (D), tree height $(\mathrm{H})$ and a conventional tree volume table, construct the aerial tree volume table.

In this study, method (ii) was used and individual tree volumes were not measured in the field. This approach is simpler and much faster than method (i), and several different tree volume tables (total or merchantable, cubic foot or board foot volume tables) can be readily established from entering tables based on diameter at breast height. However, no basic relationships between tree volume and other variables can be developed.

Previous investigations revealed that crown width is highly correlated with D (Eule 1959, Feree 1953, Krajicek et al. 1961, Minor 1951, Smith et. al. 1961, Vezina 1962 and 1963, Warrack 1959 and Wile 1963). Other investigators (Ilvessalo 1950, Nash 1948, Spurr 1960 and Willingham 1957) pointed out that the inclusion of tree height improves the correlation with $D$.

Red pine ( $P$. resinosa Ait.) was selected for investigation, and the independent variables of crown width, total height, canopy density, crown class and site were chosen for the correlation analysis.

\section{(b) Field Work}

During the summer of 1962, data from 594 red pines were obtained at the Petawawa Forest Experiment Station. The measurements were made in 23 natural stands and included:

Diameter at breast height (D): measured with a diameter tape to the nearest $1 / 10$ inch.

Crown width (W): measured with a metallic tape to the nearest foot. Two sets of measurements by vertical projections were made on standing trees:

(i) total crown width $\left(W_{1}\right)$ : one measurement of crown width at the widest point, and the other at right angles thereto.

(ii) effective crown width $\left(W_{2}\right)$ : two measurements, at right angles, in which protruding branches and indentations of crown are disregarded.

An additional variable, $W_{3}=$ the average of $W_{1}$ and $W_{2}$ was calculated. $\mathrm{W}_{3}$ is similar to the "visible crown diameter" described by Dilworth (1956).

Height $(\mathrm{H})$ : total tree height, measured with the Spiegel Relascope to the nearest foot.

Crown Length (L): length of green crown, measured with the Spiegel Relascope to the nearest foot. 
Canopy Density (C): measured for each stand in 10\% classes with the Moosehorn (a modified version of the instrument described by Robinson (1947)).

Crown Class (C.C.): Class 1: dominant and codominant. Class 2: intermediate and suppressed. Only two classes were used because an analysis of preliminary data resulted in a significant difference between these two classes only, not between all four common classes.

Site (S): Three classes based on soil moisture having the following approximate site indices (S.I., based on height at 50 years):
good
(I): S.I. $=60+\mathrm{ft}$
medium
(II): S.I. $=45-60 \mathrm{ft}$
poor
(III): S.I. $=45-\mathrm{ft}$.

In Table 1, some pertinent statistics of the data collected are listed.

TABLE 1

Statistics of Field Data

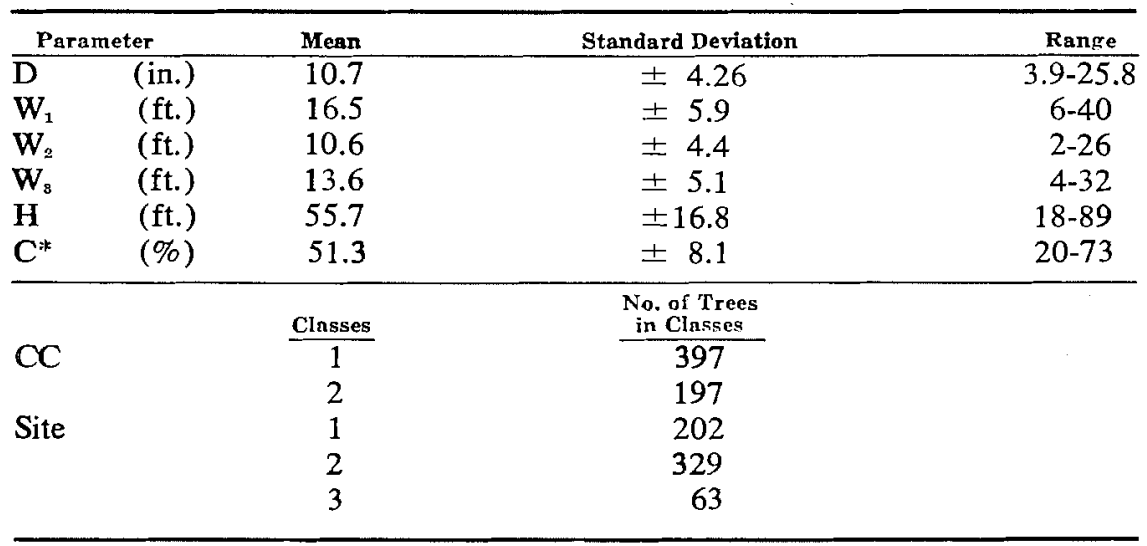

* Calculated from stand averages.

REGRESSION ANALYSIS

The computer program included the following variables:

$$
\begin{aligned}
& \mathbf{Y}=\text { diameter at breast height } \\
& \mathrm{X}_{1}=\text { crown width } \\
& \mathrm{X}_{2}=\text { total tree height } \\
& \mathrm{X}_{\mathrm{s}}=\text { canopy density } \\
& \mathrm{X}_{\mathrm{t}}=\text { crown class } \\
& \mathrm{X}_{\mathrm{u}}=\text { site class } \\
& \mathrm{X}_{32}=\mathrm{X}_{2} \mathrm{X}_{3} \mathrm{X}_{4} \mathrm{X}_{5} \\
& \mathrm{X}_{1 \mathrm{~B}}=\mathrm{X}_{1}^{3} \\
& \mathrm{X}_{14}=\mathrm{X}_{1} \mathrm{X}_{2} \\
& \begin{array}{l}
X_{15}=X_{1} X_{3} \\
X_{10}=X_{1} X_{4}
\end{array} \\
& \mathrm{X}_{17}=\mathrm{X}_{1} \mathrm{X}_{6} \\
& \mathrm{X}_{1 \mathrm{~s}}=\mathrm{X}_{1} \mathrm{X}_{\mathrm{2}} \mathrm{X}_{\mathrm{s}} \\
& \mathrm{X}_{10}=\mathrm{X}_{1} \mathrm{X}_{3} \mathrm{X}_{4} \\
& \mathrm{X}_{20}=\mathrm{X}_{1} \mathrm{X}_{5} \mathrm{X}_{5} \\
& \mathrm{X}_{\mathrm{m}}=\mathrm{X}_{1} \mathrm{X}_{2} \mathrm{X}_{4} \\
& \mathrm{X}_{22}=\mathrm{X}_{1} \mathrm{X}_{2} \mathrm{X}_{5} \\
& \mathrm{X}_{23}=\mathrm{X}_{1} \mathrm{X}_{2} \mathrm{X}_{8} \mathrm{X}_{4} \\
& \mathrm{X}_{24}=\mathrm{X}_{1} \mathrm{X}_{2} \mathrm{X}_{3} \mathrm{X}_{1} \mathrm{X}_{\overline{\mathrm{s}}}
\end{aligned}
$$$$
\mathrm{X}_{\mathbf{6}}=\mathrm{X}_{2} \mathrm{X}_{\mathbf{2}}
$$$$
\mathrm{X}_{7}=\mathrm{X}_{3} \mathrm{X}_{4}
$$$$
\mathrm{X}_{0}=\mathrm{X}_{2} \mathrm{X}_{4}
$$ 
Having established these independent variables, the data were subjected to a multiple regression analysis ${ }^{3}$. The particular method used was the stepwise approach (Brown, 1961), which is described as follows:

(i) having calculated the total variance of the dependent variable, the independent variable ( $\mathrm{X}_{\mathrm{p}}$, for example) contributing the most variance is located, and the equation $\mathrm{Y}=\mathrm{a}+\mathrm{bX}$ is computed.

(ii) the variance of the remaining 23 independent variables is calculated, and the variable $\left(X_{q}\right.$, for example) which now contributes the most variance is located; the equation $Y=a^{\prime}+b^{\prime} X_{p}+c X_{q}$ is computed.

In this fashion, more variables may be added to the equation and more variance accounted for.

A criterion for the selection of variables is that the final equation should not include variables which increase the amount of work necessary to find $D$ without a significant increase in the precision of the equation. Another consideration is that the inclusion of many variables in the equation may improve the fit of the regression line to the sample data, but not necessarily to the population. To decide which variables should be included, the test of significance proved unusable, as it indicated $1 \%$ significance levels for most of the variables tested. Alternatively, the additional variance contributed by each variable was chosen.

\section{RESULTS AND DISCUSSION}

Some researchers investigating the $\mathrm{D} / \mathrm{W}$ relationship came to the conclusion that $W^{2}$ or crown volume would exhibit a better correlation with $D$ than $W$ (Dahl 1954, Deetlefs 1954, Eule 1959). To test these possibilities, variables of $W^{3}$ and crown volume (paraboloid and conical) were calculated using $W_{1}$ and crown length. The regression analysis was carried out, substituting in turn each of the above variables for crown width. It was found that none of these variables gave as good a correlation with $\mathrm{D}$ as $\mathrm{W}_{1}$ and were therefore rejected.

To find out which of the remaining variables would result in the best correlation with $\mathrm{D}$, the regression analysis was carried out three times, once for each of $W_{1}, W_{2}$ and $W_{3}$. Results of the analyses are listed in Tables 2 and 3.

Table 2 , in which the variance contributed by the simple variables is listed, reveals that crown width in general has a better correlation with diameter at breast height than the other variables, and that $W_{1}$ in particular is better than $\mathrm{W}_{2}$ and $\mathrm{W}_{3} ; \mathrm{W}_{2}$ and $\mathrm{W}_{3}$ were therefore rejected.

In Table 3 , the variances contributed by the 24 variables are listed for $\mathrm{X}_{1}=\mathrm{W}_{1}$. The product of crown width and tree height $\left(\mathrm{X}_{14}\right)$ exhibits the greatest correlation with diameter at breast height (Y). Removing the covariance between $X_{14}$ and the other variables, it becomes immediately apparent that these remaining variables contribute a very small amount of independent variance. These findings are consistent with those reported by Minor (1960). However, several other investigators (Barnes 1953, Krajicek et al. 1961, and Smith et al. 1961) noted that spacing or stand density does influence the D/W

3 The author wishes to acknowledge the invaluable help of Dr. A. L. Wilson of the Statistical Research Service, Department of Forestry, in programming and executing the regression analysis. 
TABLE 2

VARIANCE (IN \% OF TOTAL) CONTRIBUTED BY SIMPLE VARIABLES

\begin{tabular}{lccc}
\hline \multicolumn{1}{c}{ Variable } & \multicolumn{2}{c}{ \% variance } & $\mathbf{W}_{\mathbf{8}}$ \\
\hline crown width $\left(\mathrm{X}_{1}\right)$ & 85 & $\mathbf{W}_{2}$ & 79 \\
height $\left(\mathrm{X}_{2}\right)$ & & 81 & \\
crown class $\left(\mathrm{X}_{\mathrm{s}}\right)$ & & 37 & \\
canopy density $\left(\mathrm{X}_{4}\right)$ & & 0.5 & \\
site $\left(\mathrm{X}_{5}\right)$ & & 0.02 & \\
\hline
\end{tabular}

TABLE 3

VARIANCE (IN \% OF TOTAL) CONTRIBUTED BY VARIABLES

\begin{tabular}{|c|c|c|c|c|c|}
\hline Variable & $\begin{array}{c}\text { Before } \\
\text { removal } \\
\text { of } \\
\text { covariance } \\
\text { with } \\
\mathbf{X}_{14} \\
\end{array}$ & $\begin{array}{c}\text { After } \\
\text { removal } \\
\text { of } \\
\text { covariance } \\
\text { with } \\
\mathbf{X}_{14} \\
\end{array}$ & Variable & $\begin{array}{c}\text { Before } \\
\text { removal } \\
\text { of } \\
\text { covariance } \\
\text { with } \\
\mathbf{X}_{14} \\
\end{array}$ & $\begin{array}{c}\text { After } \\
\text { removal } \\
\text { of } \\
\text { covariance } \\
\text { Fith } \\
\mathrm{X}_{14} \\
\end{array}$ \\
\hline $\mathrm{X}_{1}=\mathrm{W}_{1}$ & 85 & 5.2 & $X_{18}=X_{1}^{2}$ & 83 & 4.5 \\
\hline $\mathrm{X}_{2}=\mathbf{H}$ & 37 & 2.4 & $X_{14}=X_{1} X_{2}$ & 86 & - \\
\hline $\mathrm{X}_{\mathrm{s}}=\mathrm{CC}$ & .5 & 2.2 & $\mathbf{X}_{16}=\mathbf{X}_{1} \mathbf{X}_{3}$ & 55 & .1 \\
\hline$X_{4}=C D$ & 31 & 2.8 & $X_{10}=X_{1} X_{4}$ & 21 & .2 \\
\hline $\mathrm{X}_{\mathrm{v}}=\mathrm{S}$ & .02 & 1.1 & $X_{27}=X_{1} X_{5}$ & 34 & 3.3 \\
\hline$X_{0}=X_{2} X_{8}$ & 15 & 3.1 & $\mathbf{X}_{18}=\mathbf{X}_{1} \mathbf{X}_{2} \mathbf{X}_{8}$ & 62 & 2.1 \\
\hline $\mathrm{X}_{7}=\mathrm{X}_{8} \mathrm{X}_{\mathbf{4}}$ & 22 & 3.6 & $X_{10}=X_{1} X_{3} X_{4}$ & 8.1 & 2.1 \\
\hline $\mathrm{X}_{8}=\mathrm{X}_{\mathrm{g}} \mathrm{X}_{5}$ & 1.2 & .2 & $X_{20}=X_{1} X_{8} X_{5}$ & 28 & .3 \\
\hline$X_{0}=X_{2} X_{4}$ & .32 & 3.0 & $\mathrm{X}_{\mathrm{z}}=\mathrm{X}_{1} \mathrm{X}_{2} \mathrm{X}_{4}$ & 42 & 2.4 \\
\hline$X_{10}=X_{2} X_{5}$ & 18 & .1 & $X_{22}=X_{1} X_{2} X_{5}$ & 59 & 1.3 \\
\hline$X_{11}=X_{2} X_{9} X_{4}$ & .78 & 3.5 & $\mathrm{X}_{2 \mathrm{~s}}=\mathrm{X}_{1} \mathrm{X}_{2} \mathrm{X}_{3} \mathrm{X}_{4}$ & 26 & 3.7 \\
\hline$X_{12}=X_{2} X_{8} X_{4} X_{5}$ & 1.9 & 2.2 & $\mathrm{X}_{24}=\mathrm{X}_{1} \mathrm{X}_{2} \mathrm{X}_{8} \mathrm{X}_{4} \mathrm{X}_{6}$ & 17 & 1.2 \\
\hline
\end{tabular}

relationship, and one might expect that canopy density in this analysis would account for a significant amount of variance. This is not the case, and several reasons are possible:

(i) the range of the average stand canopy densities is limited, thus limiting any effect $C$ might have had on the $W / D$ relationship;

(ii) the canopy density within each stand varies greatly, which precludes showing differences between stands;

(iii) the $\mathrm{D} / \mathrm{W}$ relationship of a particular tree would be influenced by the density of the immediately adjacent trees rather than the stand average.

To improve the correlation without increasing the number of independent variables to be measured, it was decided to include in the final equation the product of crown width and tree height $\left(X_{14}\right)$ plus crown width $\left(X_{1}\right)$ and tree height $\left(\mathrm{X}_{2}\right)$. 
The equation therefore has the form

$$
\mathbf{Y}=\mathrm{a}+\mathrm{bX}_{1} \mathbf{X}_{2}+\mathrm{cX}_{1}+\mathrm{dX}_{2}
$$

where $X_{1}=$ total crown width and $X_{2}=$ total tree height. Calculating the coefficients and substituting $Y=D, X_{1}=W$ and $X_{2}=H$, we have

$$
\mathrm{D}=-2.687+0.000140 \mathrm{WH}+0.5766 \mathrm{~W}+0.06766 \mathrm{H}
$$

This equation accounts for $91.5 \%$ of the total variance of the data, and has a multiple correlation coefficient $\mathbf{R}=0.957$ and a standard error of estimate of \pm 1.24 inches (Snedecor, 1959).

Table 4 showing diameter at breast height in terms of crown width and total height was prepared from equation 1.

TABLE 4

\begin{tabular}{|c|c|c|c|c|c|c|c|}
\hline \multirow{3}{*}{$\begin{array}{l}\text { Crown } \\
\text { Width } \\
\text { (ft.) }\end{array}$} & \multicolumn{7}{|c|}{ Total height of tree in feet } \\
\hline & 30 & 40 & 50 & 60 & 70 & 80 & 90 \\
\hline & \multicolumn{7}{|c|}{ Diameter breast height (in ches) } \\
\hline 6 & 2.8 & 3.5 & 4.2 & 4.9 & & & \\
\hline 8 & 4.0 & 4.7 & 5.4 & 6.1 & 6.7 & & \\
\hline 10 & 5.2 & 5.8 & 6.5 & 7.2 & 7.9 & 8.6 & \\
\hline 12 & & 7.0 & 7.7 & 8.4 & 9.1 & 9.8 & \\
\hline 14 & & 8.2 & 8.9 & 9.6 & 10.3 & 11.0 & \\
\hline 16 & & & 10.0 & 10.7 & 11.4 & 12.1 & 12.8 \\
\hline 18 & & & 11.2 & 11.9 & 12.6 & 13.3 & 14.0 \\
\hline 20 & & & 12.4 & 13.1 & 13.8 & 14.5 & 15.2 \\
\hline 22 & & & & 14.2 & 15.0 & 15.7 & 16.4 \\
\hline 24 & & & & 15.4 & 16.1 & 16.8 & 17.6 \\
\hline 26 & & & & 16.6 & 17.3 & 18.0 & 18.7 \\
\hline
\end{tabular}

TREe Diameter TABLE - RED PINE

By means of equation (1), which was used to calculate $D$ to the nearest $1 / 10$ inch from $W$ and $H$, and interpolated values of "Form Class Volume Tables" (1948) (form class 70, red pine under 120 years, total volume in cubic feet), the red pine tree volume table shown in Table 5 was constructed.

Equation (1) should not be used to expand the tables beyond the limits of Table 5, because the sample data were insufficient for establishing 2 significant D/WH relationship beyond these limits.

\section{Testing the Table}

Data were obtained from 27 red pines, which in the spring of 1962 had been measured in the field and on large-scale (1:330) aerial photographs. The randomly selected trees were situated in 6 coniferous stands, located at Petawawa Forest Experiment Station. In the field, D, W and $\mathrm{H}$ were measured for each tree; on the photos, $\mathrm{W}$ and $\mathrm{H}$ were measured for each tree. From the field measurements of $D$ and $H$, individual tree volumes were obtained by means of Form Class Volume Tables (1948). From the photomeasured $\mathrm{W}$ and $\mathrm{H}$, another set of tree volumes were obtained by means of Table 5 . 
TABLE 5

TREe VOLUME TABLE - RED PINE

\begin{tabular}{cccccccc}
\hline $\begin{array}{c}\text { Crown } \\
\text { Width } \\
\text { (ft.) }\end{array}$ & \multicolumn{7}{c}{ Total height of tree in feot } \\
\hline & $\mathbf{3 0}$ & $\mathbf{4 0}$ & $\mathbf{5 0}$ & $\mathbf{6 0}$ & $\mathbf{7 0}$ & $\mathbf{8 0}$ & $\mathbf{9 0}$ \\
\hline 6 & 1 & 1 & 2 & 4 & & & \\
\hline 8 & 1 & 2 & 4 & 5 & 8 & & \\
10 & 2 & 3 & 5 & 7 & 10 & 14 & \\
12 & & 5 & 7 & 10 & 14 & 18 & \\
14 & & 7 & 10 & 13 & 17 & 23 & \\
16 & & & 12 & 16 & 21 & 27 & 34 \\
18 & & & 15 & 20 & 26 & 33 & 40 \\
20 & & & 19 & 24 & 31 & 39 & 47 \\
22 & & & & 28 & 36 & 45 & 55 \\
24 & & & & 33 & 42 & 52 & 63 \\
26 & & & & 39 & 48 & 59 & 71 \\
\hline
\end{tabular}

TABLE 6

Statistics PERTINENT TO THE TEST OF THE TABLE

\begin{tabular}{llll}
\hline & \multicolumn{1}{c}{$\mathrm{w}_{\mathrm{D}}$} & \multicolumn{1}{c}{$\mathrm{H}_{\mathrm{D}}$} & \multicolumn{1}{c}{$\mathrm{V}_{\mathrm{D}}$} \\
\hline Bias & $-1.4 \mathrm{ft}$. & $-2.2 \mathrm{ft}$. & $-2.1 \mathrm{cu} . \mathrm{ft}$. \\
In \% of mean & -7 & -3 & -6 \\
Standard deviation of difference & $\pm 2.11 \mathrm{ft}$. & $\pm 3.17 \mathrm{ft}$. & $\pm 8.4 \mathrm{cu} . \mathrm{ft}$. \\
In \% of mean & \pm 11 & \pm 4 & \pm 24
\end{tabular}

$W_{D}=$ difference between photo-measured and ground-measured crown widths.

$\mathrm{H}_{D}=$ difference between photo-measured and ground-measured tree heights.

$\mathrm{V}_{D}=$ difference between individual tree volumes derived from photo-measurements and individual tree volumes derived from ground-measurements.

The figures in the first two columns of Table 6 show that crown width and tree height can be measured fairly accurately on aerial photographs; recent tests on improved photographs made by members of the Forest Inventories Section indicate that these errors can be further reduced.

In the last column of Table 6, the standard deviation of difference reveals a great lack of precision which indicates that individual tree volumes can not be measured accurately by means of this method; however, the bias is within acceptable limits, which indicates that the total volume of even a small number of trees can be determined from measurements on aerial photographs with sufficient accuracy. 


\section{Literature Cited}

ANONYMOUS. 1948. Form Class Volume Tables (second edition). Department of Mines and Resources, Dominion Forest Service, Ottawa.

BARNES, G. H. 1953. Yield of Even-aged Stands of Western Hemlock. Preliminary Report, P.N.W. Forest and Range Experiment Station.

BROWN, D. M. 1961. Least Squares Linear Regression Analysis for 1 Dependent and 24 Independent Variables. Statistical Research Service, Forest Entomology and Pathology Branch, Department of Forestry. File \#06-01-001.

DAHL, B. 1954. Assessment of Standing Timber Volumes from Aerial Photographs. Australian Forestry, Vol. 18(1).

DEETLEFS, P. P. duT. 1954. The Relationship between Stand Density, Crown Size and Basal Area Growth in Stands of Pinus taeda L. in the Native Habitat of this Species. Journal of the South African Forestry Association \#24.

DIL WORTH, J. R. 1956. The Use of Aerial Photography in Cruising Second Growth Douglas Fir Stands. Ph.D. Thesis, University of Washington.

EULE, H. W. 1959. Methods of Crown Measurement and the Relations Between Crown Size, Stem Diameter and Increment of Beech. Allgemeine Forst and Jagdzeitung, Vol. 130(7).

EVANS, W. R. and J. M. CHRISTIE. 1957. Provisional Yield Tables for Western Hemlock in Great Britain. For Comm. For Rec. No. 33.

FEREE, M. J. 1953. Estimating Timber Volumes from Aerial Photographs. State University College of Forestry, Syracuse, N.Y.

ILVESSALO, Y. 1950. On the Correlation between the Crown Diameter and the Stem of Trees. Communicationes Instituti Forestalis, Fenniae Vol. 38 (2) (reprint), Helsinki.

KIPPEN, F. W. and L. SAYN-WITTGENSTEIN. 1964. Tree Measurements on Large-Scale, Vertical, $70 \mathrm{~mm}$. Air Photographs. Dept. of Forestry Publication (in press). Forest Research Branch, Dept. of Forestry, Canada.

KRAJICEK, J. E., K. A. BRINKMAN, and S. P. GINGRICH. 1961. Crown CompetitionA Measure of Density. Forest Science, Vol. 7(1).

LYONS, E. H. 1961. Preliminary Studies of Two Camera, Low-Elevation Stereo-Photography from Helicopters. Photogramm. Eng. Vol. 27(1).

MINOR, C. O. 1951. Stem-crown Diameter Relations in Southern Pine. Journal of Forestry, Vol. 49.

MINOR, C. O. 1960. Estimating Tree Diameters of Arizona Ponderosa Pine from Aerial Photographs. Rock Mountain Forest and Range Experiment Station, Research Note \#46.

NASH, A. J. 1948. Some Volume Tables for Use in Air Survey. Forestry Chronicle, Vol. 24(1).

ROBINSON, M. W. 1947. An Instrument to Measure Forest Crown Cover. Forestry Chronicle $\# 23$.

SMITH, J. H. G., J. W. KER, and L. HEGER. 1960. Natural and Conventional Height-age Curves for Douglas Fir and Some Limits to Their Refinement. World For. Congress, Seattle, SP/87/F-Canada.

SMITH, J. H. G., J. W. KER, and J. CSIZMAZIA. 1961. Economics of Reforestation of Douglas Fir, Western Hemlock and Western Red Cedar in the Vancouver Forest District. Forestry Bulletin \#3, Faculty of Forestry, University of British Columbia (Table 25, p. 44).

SNEDECOR, G. W. 1959. Statistical Methods (Fifth Edition). The Iowa State College Press, Ames, Iowa (p. 420).

SPURR, S. H. 1960. Aerial Photographs in Forestry. Ronald Press Co., New York.

VEZINA, P. E. 1962. Crown Width - D.B.H. Relationships for Open-grown Balsam Fir and White Spruce in Quebec. Forestry Chronicle, Vol. $38(4)$.

VEZINA, P. E. 1963. More About the Crown Competition Factor. Forestry Chronicle Vol. 39(3).

WARRACK, G. C. 1959. Crown Dimension, Initial Diameter and Diameter Growth in a Juvenile Stand of Douglas Fir. For. Chron. 35: 150-153.

WILE, B. C. 1963. Crown Size and Stem Diameter in Red Spruce and Balsam Fir. Proposed Departmental Publication, Dept. of Forestry, For. Res. Br. (Mimeograph 63-M-17).

WILLINGHAM, J. W. 1957. Estimation of Forest Management Inventory Data from Aerial Photographic Measurements. Forest Science, Vol. 3(3). 